DOI: https://doi.org/10.47405/mjssh.v5i5.416

\begin{tabular}{|c|c|}
\hline 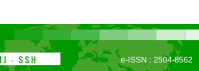 & Malaysian Journal of Social Sciences and Humanities (MJSSH) \\
\hline Malaysian Journal of & Volume 5, Issue 5, May 2020 \\
\hline $\begin{array}{l}\text { Humantitus } \\
\text { (MJ - SSH) }\end{array}$ & e-ISSN : 2504-8562 \\
\hline & $\begin{array}{l}\text { Journal home page: } \\
\text { www.msocialsciences.com }\end{array}$ \\
\hline
\end{tabular}

\title{
Internet Banking Among Baby Boomers: A Case Study on Customer Satisfaction in Bangsar, Kuala Lumpur
}

\author{
Yeap Pei Xin1, Vasithra Devamanickam1, Nur Izyan Syazwani Binti Ismail Marzuki1, Siti Nur Aminah \\ Binti Wan Ahmad Daknam1, Siti Noratikah Binti Adnan1, Nur Sharina Binti Muhammad Khairul', \\ Nur Hikmah Binti Ramli', Isai Amutan Krishnan², Geraldine De Mello ${ }^{3}$, Vasudevan Naidu Kanan4, \\ Shasthrika Baskaran1, Kausalya Muthutamilselvan ${ }^{5}$ \\ 1University of Malaya Centre for Continuing Education (UMCCed), University of Malaya (UM) \\ ${ }^{2}$ Faculty of Languages and Linguistics, University of Malaya (UM) \\ ${ }^{3}$ Academy of Language Studies, Universiti Teknoligi MARA (UITM) \\ ${ }^{4} \mathrm{O}$ 'Connor's Engineering Sdh. Bhd \\ ${ }^{5}$ Lorong 2A/5, Taman Mutiara, Sg. Kob Karangan
}

Correspondence: Isai Amutan Krishnan (amuthan.isai@gmail.com)

\begin{abstract}
The present study focuses on the factors relating to why Baby Boomers are reluctant to adopt internet banking and to investigate the level of convenience experienced when using it. A quantitative method was employed to analyse the data based on the conceptual framework. A survey questionnaire was chosen as the research instrument. The findings show that the two independent variables, service quality and convenience, did not correlate, but there was a significant affect from customer satisfaction with internet banking among the Baby Boomer respondents. The R-squared value was 0.928 , meaning that $92.8 \%$ of the both independent variables affected the dependent variable. Another $7.2 \%$ was indicated for other independent variables not used in this study.
\end{abstract}

Keywords: baby boomers, customer satisfaction, convenience, service quality, internet banking

\section{Introduction}

The market potential is important as internet banking is capable not only of meeting the needs of professionals anytime, anywhere, but also of reaching out to those who do not already use internet banking (Asian Finance Institute, 2016). Bank Negara Malaysia (2019) found that in 2019, 90.7\% of Malaysians (29.4 million people) were willing to use internet banking services as the services are available. However, the Malaysian Communications and Multimedia Commission (2017) showed that most non-internet users' unwillingness to go online was attributed to age, $74.3 \%$ of whom were Baby Boomers. As per Gilliam, Chatterjee and Zhu (2010) definition, Baby Boomers denote to a group of people who are moderate to acknowledge unused innovation and battle to get it the ways to utilize it when they acknowledge, and they were born between 1946 and 1964 (McLeod, 2009; Poon, Yong \& Lam, 2009; Mashal \& Ahmed, 2015).

Rejection of internet banking is one of the most important problems that faces banks in developing countries (Al-Ajam \& Nor, 2013). Therefore, a few studies were done on internet banking in Malaysia, and the previous studies have only focused on generations other than Baby Boomers. Banks began introducing internet banking in the year 2000 and have worked to convince the public to adopt it, but 
Baby Boomers are still reluctant to adopt it. The non-internet banking users are likely older (Ahmed \& Phin, 2016). According to Camilleri and Grech (2017), most non-user respondents in their study fell within the 50-68 years of age group. Older people may need to face the challenges in using the new technologies (Morris, Venkatesh \& Ackerman, 2005).

The issue of increasing the adoption rate of internet banking among Baby Boomers has grown in importance considering recent trends. In addition, Baby Boomers also feel insecure when using internet banking (World Health Organisation, 2015; 2010; Camilleri \& Grech, 2017). In consonance with Goh, Yeo, Lim and Tan (2016), confidentiality is an essential element which always concerns customers as customers often doubt that the banks can protect their personal and financial information, especially when they do transactions via internet banking. According to the MCMC (2017), most non-internet users refuse to go online due to privacy concerns. Moreover, Bradley and Stewart (2003) and Suh and Han (2002) pointed out that internet banking trust is important since the transaction consists of sensitive information and the people who did the transactions are worried about when deals with the internet.

Therefore, the purposes of this study to investigate the reasons why Baby Boomers are reluctant to follow internet banking and to investigate the level of convenience among Baby Boomers in internet banking.

\section{Literature Review}

\section{Internet Banking}

Banks have invested heavily in the development of internet banking, which acts as a kind of budgetary between in making interactions via network (Vuori \& Holmlund-Rytkönen, 2005 ; Nupur, 2010; Ahanger, 2011). Internet banking will continue to revolutionize the current traditional banking industry and offer more opportunities to better meet consumer service needs through enhanced interaction, data mining and customization in internet banking services (Weingarten, 2009; Firdous and Farooqi, 2017). Internet banking has empowered clients to survey their keeping money exercises at their comfort. Clients and trade proprietors can survey their keeping money exercises in their daily basis if they could connect to the internet (Gorrell, 2008; Weingarten, 2009; Hawkins, Mothersbaugh \& Best, 2010; Lee, Chia, Choong \& Foo, 2017).

\section{Baby Boomers}

According to Frey (2010) and Hilt and Lipschultz (2005), Baby Boomers are more highly educated, more likely to occupy professional and managerial positions, and more racially and ethnically diverse than their predecessors. Quinn (2010) and Grech (2017) mentioned that they have more varied work histories, longer transitions out of the labour force, and work for more of their adult years. Hilt and Lipschultz (2005; Porter \& Donthu, 2006) mentioned that aging Baby Boomers have been enthusiastic about use of the internet and other new media. Unlike some of their parents' generation, Boomers learned to use computers and the World Wide Web in the workplace. Baby Boomers are more techsavvy than previous generations. However, the Baby Boomers have not been receiving enough attention from marketers, who have been more aggressively targeting the younger generations.

\section{Customer Satisfaction}

According to Muffato and Panizzolo (1995), Levesque and McDougall (1996) and Isa and Fontaine (2011), customer satisfaction is one of the most important competitive factors and the best indicator of a company's profitability. In turn, customer satisfaction would allow a company to enhance its credibility and identity, minimize customer defection and increase sensitivity to customer needs, thereby creating barriers to brand change and enhancing business relations with its customers (Gronroos, 2000; Fornell, Johnson, Anderson, Cha \& Bryant 1996). Gratification is also predisposed by clients'demonstrativeretorts, their ascriptions and their insights of impartiality (Reichheld, 1993; 
Zeithal \& Bitner, 2003, pp. 87-89) Current customers are more advantageous and profitable to banks than new customers (Naik, Gantasala \& Prabhakar, 2010; Tao, 2014).

\section{Service Quality and Customer Satisfaction}

In this arena, customers' perceptions of service quality play an essential role in the buyer's perception of the supplier's product and service, and it adds value to a product and builds enduring relationships (Said, Shuib, Ayob \& Yaakub, 2013). In consequence, the understanding of the notion of customer perception is a prerequisite for best service provision. Service quality determines the reputation of an organization, and the level of quality provided often determines what consumers think of an organization, and thus this leads to its reputation being enhanced or downgraded (Johns, 1999, p.954; Mmutle \& Shonhe, 2017). The quality of service in banking websites can boost customer satisfaction because a customer can access a variety of financial transactions in internet banking.

\section{Convenience and Customer Satisfaction}

Studies have shown (Andaleeb \& Basu, 1994; Bell (1999) or assumed (Berry, 2016) that service convenience has a positive impact on the perception of the service experience and drives customer satisfaction. Convenience is the main attraction and focus of the customers who use internet banking (Shariq, 2006; Berry, Seiders, \& Grewal, 2002; Farquhar \& Rowley, 2009; Seiders, Voss, Godfrey, \& Grewal, 2007). Many consumers turn to the internet to reduce the effort associated with making a decision (Berry et al., 2002; Beauchamp \& Ponder, 2010; Ostrom, Parasuraman, Bowen, Patrício \& Voss, 2015). These consumer resources of time and effort are defined in marketing literature as nonmonetary costs that influence purchasing behaviour (Bender, 1964; Herrmann \& Beik, 1968).

Presently, clients are continuously looking for comfort when they are overseeing their managing an account accounts and budgetary exchanges (Gehrt \& Yale, 1993; Hui, Thakor and Gill, 1998; Ong, Hong, Soh, Teh \& Tan, 2014). The clients continuously need money related administration apparatuses to be more user-friendly and have a more noteworthy inclination for items or administrations which are not advertised by conventional retail banks (Gehrt \& Yale, 1993; Berry et al., 2002; Duarte, Costa eSilva \& Ferreira, 2018).

\section{Past Studies}

There were several studies have conducted. Goh, Yeo, Lim, and Tan (2016), conducted study on the factors that influence customer satisfaction towards internet banking, arrived the result that web design and content, convenience and speed are closely linked to customer satisfaction towards internet banking. Also, there were two studies conducted in Pakistan by Rahi, Ghani, Alnaser and Yasin (2017) and Toor, Hunain, Hussain, Ali, and Shahid (2016) with different objectives. Rahi, Ghani, Alnaserand Yasin (2017) aimed to investigate whether a TAM (Technology Acceptance Model) significantly impacts customer intention to use internet banking. Their finding was that internet banking was motivated by perceived usefulness, perceived ease of use, customer service and customer satisfaction. The paper reviewed the evidence for fostering internet banking adoption, finding customer service is the most important factor through their IPMA (Importance-Performance Map Analysis). Meanwhile, in Pakistan, Toor, Hunain, Hussain, Ali and Shahid (2016) intended to conduct a study on the effect of Ebanking variation on the satisfaction of customer. Their test was successful as it was able to identify that customers are equally contended on the e-banking services in relation of the quality of service.

Another important finding was from Ali's (2016) investigation of the factor of customer acceptance toward internet banking. The results of multiple regression analysis conducted on the final variables indicate that information about internet banking, then security and privacy, then perceived usefulness and then perceived enjoyment were the most influential factors explaining the acceptance of internet banking services. In contrast to earlier studies, research was conducted by Ndikubwimana and Berndt (2016) with the purpose of investigating customer satisfaction in banking services, in general. The investigation showed that that if a bank's physical environment and facilities are conducive to delivering good service, the customers are satisfied with the tangible aspects associated with the 
service. Further analysis found that, according to the respondents in Khan et al.'s (2016) investigation conducted in Pakistan, only three to four percent used electronic banking and 96 to 97 percent of the population were still not using the services.

Previous research by Ahmed and Phin (2016) on investigating and examining the factors influencing the adoption of internet banking in Malaysia reported that social factors strongly influence the adoption of internet banking in an emerging economy like Malaysia. The study's results show that ease of use of internet banking, usefulness of internet banking and risks of internet banking are the most important factors determining internet banking adoption. This study can be related to research done by Firdous and Farooqi (2017), where the result of the research embroiled that the web keeping money benefit quality measurements have a critical effect on the client fulfilment of web keeping money clients.

Meanwhile, the major objective of the study done by Camilleri and Grech (2017) was to investigate customers' attitudes towards internet banking and how these differ across generations. The study offers some important insights, showing that generational factors did not emerge as significant in the regression models, and the questionnaires and focus groups suggest that generations differ in their attitudes towards IT-delivery systems and choice of preferred delivery channels. The most recent study conducted by Lee, Chia, Choong and Foo (2017) was to create an understanding of the effect of autonomous factors, security and protection, client dependability, benefit quality, and comfort, towards the subordinate variable, which was client fulfilment with web managing an account in Malaysia.

A study by Augustine (2017) reported that $73 \%$ of 50-59-year-olds own a smartphone, using it for a wide range of activities such as reading the news, playing games, and making purchases. On the other hand, only $54 \%$ of $60-69$-year-olds own a smartphone, and they are less likely to turn to it for the activities listed above.

Based on the previous discussion, additional information has been gathered and more gaps need to be highlighted. Previously, it was mentioned that Lee et al. (2017) suggested that further studies could be done based on the participants' future from dissimilar peers to warrant experienced results, and this matter can be supported.

Tour, Hunain, Hussain, Ali and Shahid (2016) and Ndikubwimana and Berndts' (2016) research is concerned with satisfaction of customer on internet banking services, and it provides in the purpose of improving the service quality of the banking industry. However, there seems to be a lack of focus on which specific generation they should work on. According to Asian Institute of Finance research in 2016, while future digital users are still likely to be predominantly Gen Ys and Gen Xs, Gen X was born from 1965 to 1979 and Gen Y or Millennial was born from 1980 to 1994 . The survey suggests enhancing security and enhanced features, making digital banking more convenient for the less techsavvy like Baby Boomers as they become more interested in digital banking. Therefore, this research extends our knowledge that Boomers are the appropriate targets for a wide range of consumer offerings as there are several niches within this wide cohort.

\section{Methodology}

\section{Conceptual Framework}

Figures 1 shows conceptual framework of the present study. The dependent variable in this research is customer satisfaction, while the independent variables are convenience and service quality. As reported earlier in the literature review section, Baby Boomers ' current study emphasises service quality and convenience factors that shift customer satisfaction towards internet banking.

\section{Ethical Consideration}

The ethical considerations of the research required that there was no invasion of respondents' privacy; therefore, they were only required to provide information on their gender, year of birth, marital status, 
and education level. There was also no coercion for the respondents to answer the survey questions provided. The data collected throughout this study were ensured to be sourced from the respondents out of their kindness and willingness to cooperate. The data collected are highly protected. An approval was obtained so that it does not cross any ethical boundaries in the process (Davydd \& Levin, 2007, p.45). The approval letter was obtained from UMCCED management to conduct this study.

\section{Sampling}

The data for this study includes findings on customer satisfaction with internet banking among Baby Boomers. In this analysis were included baby boomers, people between the ages of 55 and 73 , including a few races. The data included factors related to why Baby Boomers were hesitant to embrace internet banking as well as its perceived internet banking convenience rates. This study's sample size was 274, which was justified in Krejcie and Morgan (1970). Krejcie and Morgan created an efficient method of determining the sample size needed to be representative of a given population. Twenty respondents were used for the pilot study, while the remaining 254 respondents of the sample group were used for the actual study.

\section{Instruments}

The instrumentation for this analysis was planned with research goals and research questions in mind. It was decided that the best way to prepare for this investigation was to provide questionnaires for them to fill in to Baby Boomers. Therefore, questionnaires were used with answers of the Likert scale of five points. The findings were intended to describe the factors related to why Baby Boomers are hesitant to embrace internet banking and to expose Internet banking convenience rates as viewed by the respondents.

In this study, the survey questionnaire consisted of three sections, which were sections A, B and C. Section A was the demographic profile and Section B was adopted from previous research (Lim, Lim, $\mathrm{Ng}, \mathrm{Ng} \& \mathrm{Tan}, 2013)$. As for the sections B and C used 5 Likert scale where 1= Strongly Disagree, $2=$ Disagree, $3=$ Neutral, 4=Agree and 5=Strongly Agree. According to Bowling, Burnst and Grove (1997), Likert scale use fixed choices response format and are design to measure attitudes or opinions. See Table 1.

Table 1: Reliability Test for Pilot Test

\begin{tabular}{lll}
\hline Variables & Cronbach's Alpha & N of items \\
\hline Service Quality & $0.80^{*}$ & 5 \\
Convenience & $0.922^{*}$ & 5 \\
\hline
\end{tabular}

Notes: ${ }^{*} \alpha<0.07=$ Acceptable

Table 1 shows the teliability testing was carried out and resulted in an alpha test result for Section B of 0.80. Moreover, Section C comprised self-administered questions, and it had an alpha test result of 0.922. A reliability test was performed with resulting Cronbach's alpha values for all the variables above 0.75 , as shown in Table 1 . Therefore, all the variables in this study are at acceptable levels.

\section{Results and Discussion}

This section reveals the results generated from the descriptive analysis, reliability and inferential analyses and then proceeds to a discussion of the results.

\section{Descriptive Statistics}

Figure 2 shows respondent's year of birth. There were 48 respondents $(17.52 \%)$ whose birth years ranged from 1946 to 1951 . There were also 85 respondents $(31.02 \%)$ whose birth years ranged from 1952 to 1957 . Lastly, there were 141 respondents (51.46\%) whose birth years ranged from 1958 to 
DOI: https://doi.org/10.47405/mjssh.v5i5.416

1964. The respondents were mainly from the birth year range of 1958-1964, which was the youngest group of the participating Baby Boomers aged from 55 to 61, which indicates most of them were still working and had not yet retired. The fewest respondents were from the eldest group range with the birth years of 1946-1951. Since they were the eldest individuals, they might have already retired from their jobs.

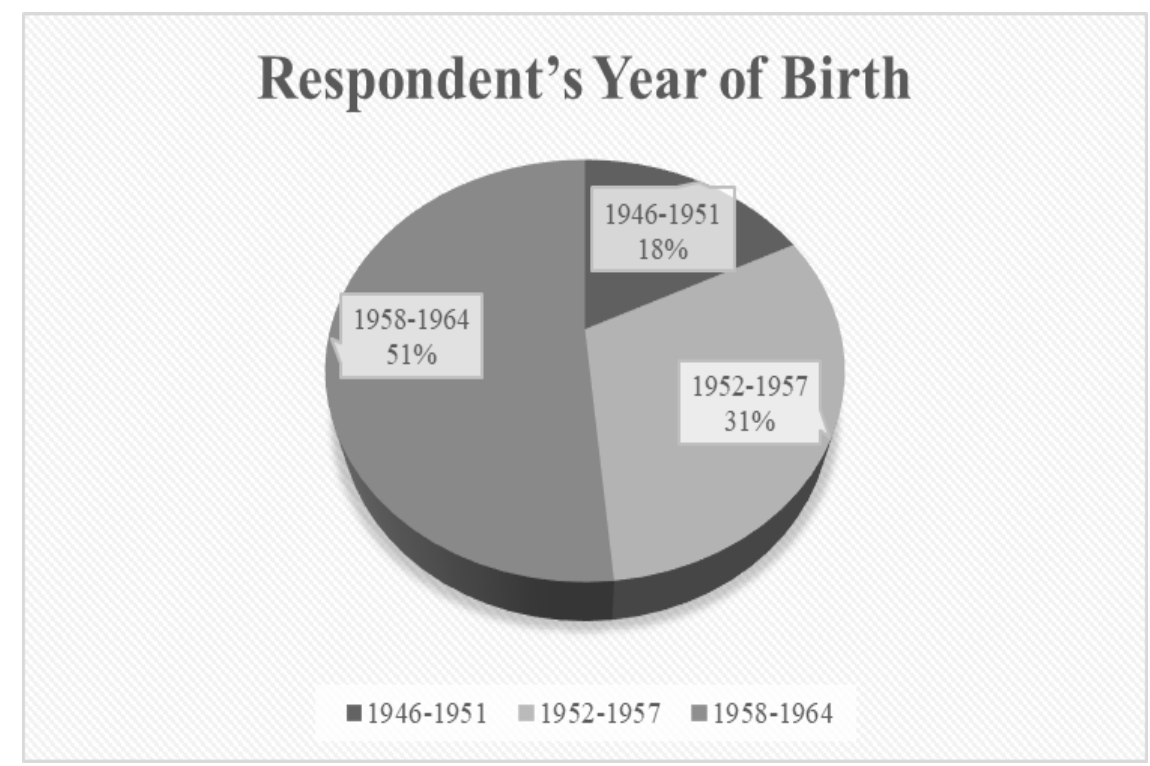

Figure 2: Respondent's Year of Birth

Figure 3 shows the numbers of gender who responded. Yhere were 141 males $(51.46 \%)$ and 133 females $(48.54 \%)$ out of the total 274 surveyed.

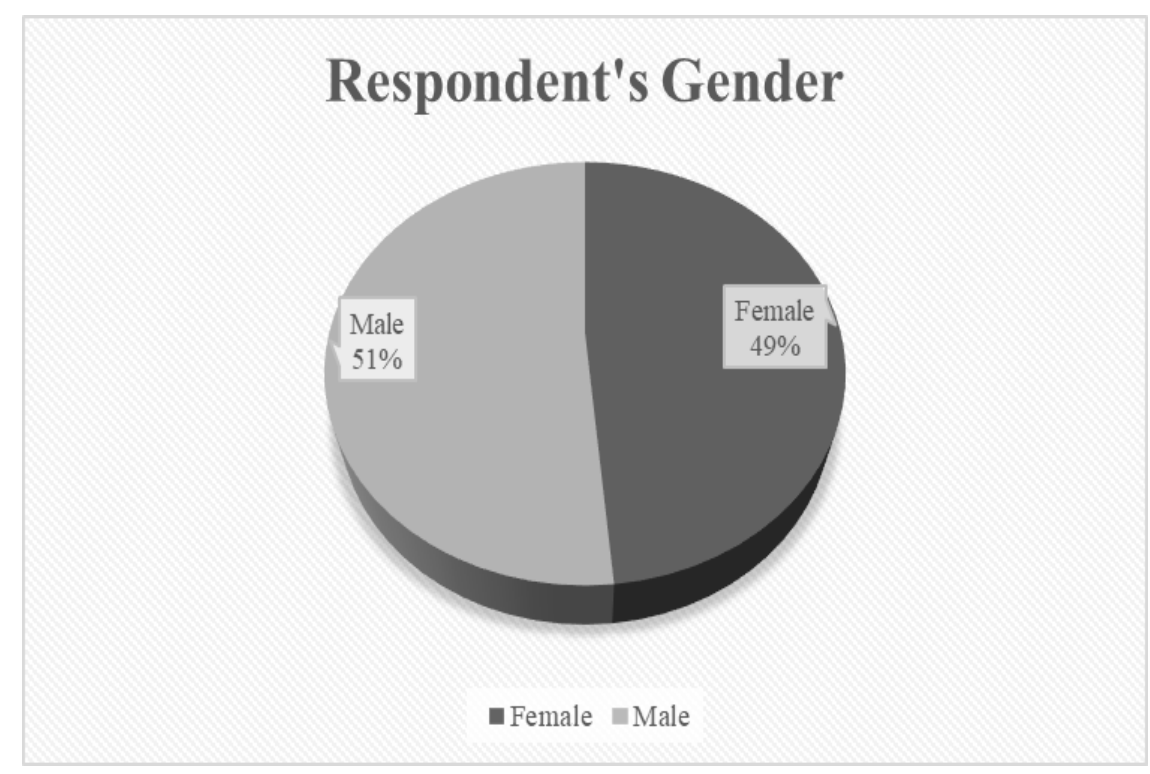

Figure 3: Respondent's Gender

Figure 4 shows the races of respondents shows that most of the respondents were Malay, who comprised $55.47 \%$ (152 respondents) of the respondents. They were followed by Indians, Chinese and others, comprising 18.98\% (52 respondents), 18.61\% (51 respondents) and 6.93\% (19 respondents), respectively. 


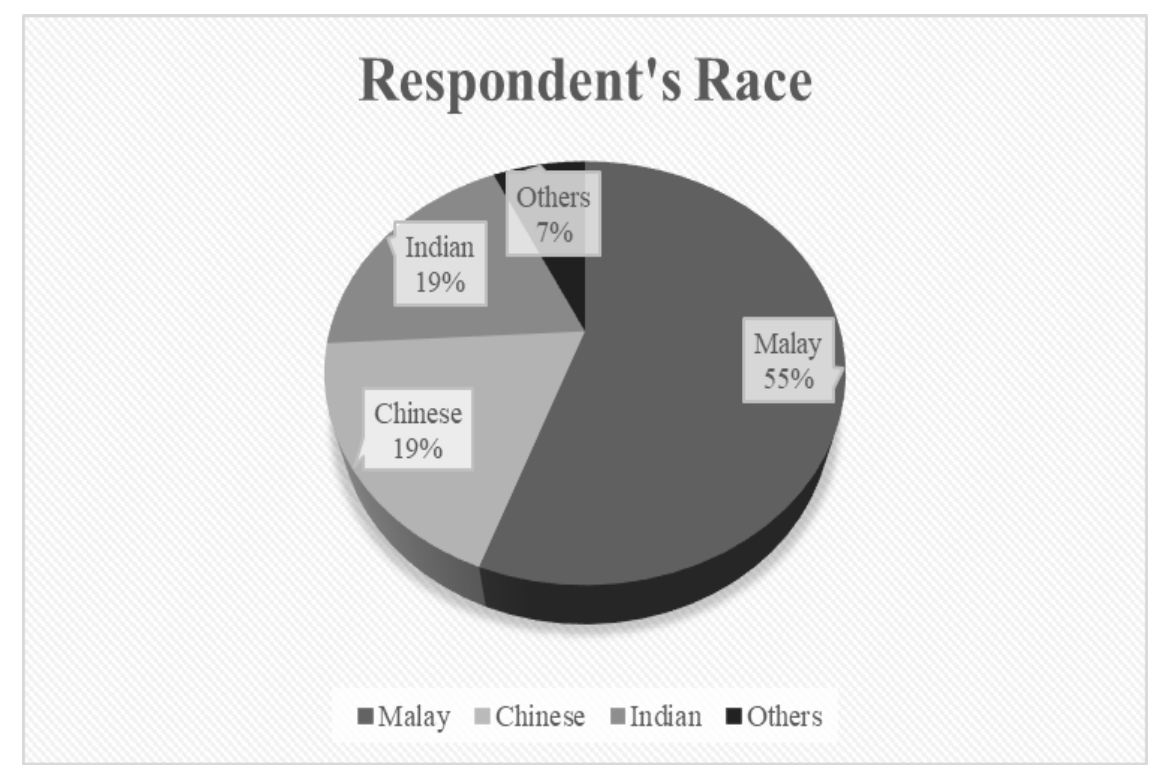

Figure 4: Respondent Races

Figure 5 demonstrates on marital status that most of the respondents were married, comprising $87.59 \%$ (240 respondents), while only $12.41 \%$ (34 respondents) were single.

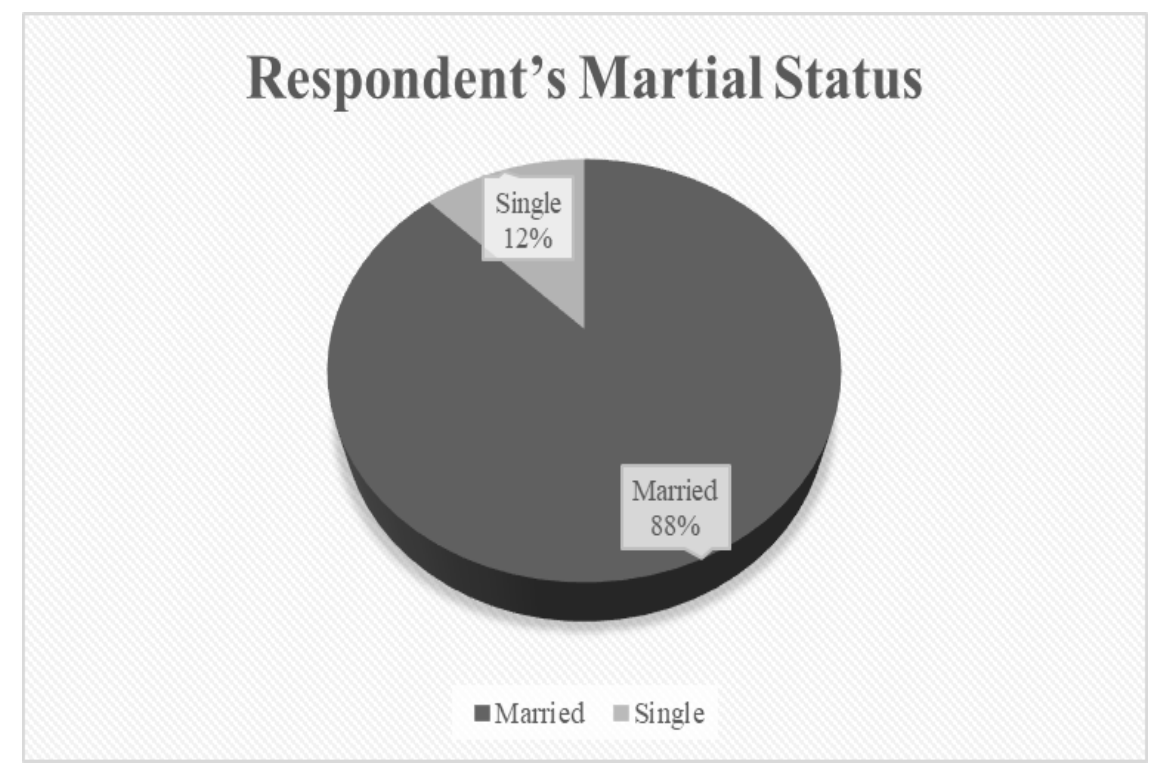

Figure 5: Respondent's Martial Status

Figure 6 shows the educational level. Most of the respondents were from high school, which consists of $120(43.80 \%)$ respondents. Following this group, $17.88 \%$ (49 respondents) from the primary school and followed by tertiary levels which are diploma and degree holders, comprising $13.87 \%$ (38 respondents) and $18.25 \%$ (50 respondents), respectively. The remaining 12 respondents were master's degree and above holders, who comprised $4.38 \%$. There were five respondents $(1.82 \%)$ who were without educational backgrounds. 


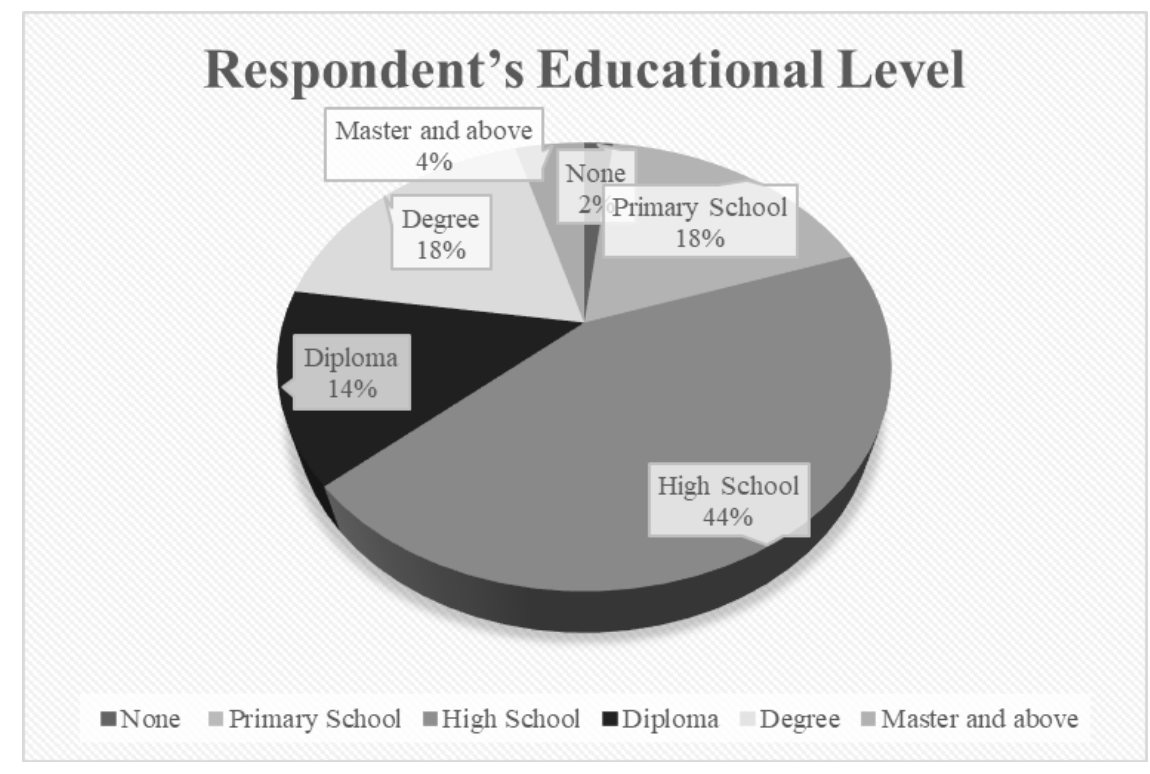

Figure 6: Respondent's Educational Level

Figure 7 shows there were 141 respondents (51.46\%) using internet banking, and 133 respondents $(48.54 \%)$ who were not internet banking users.

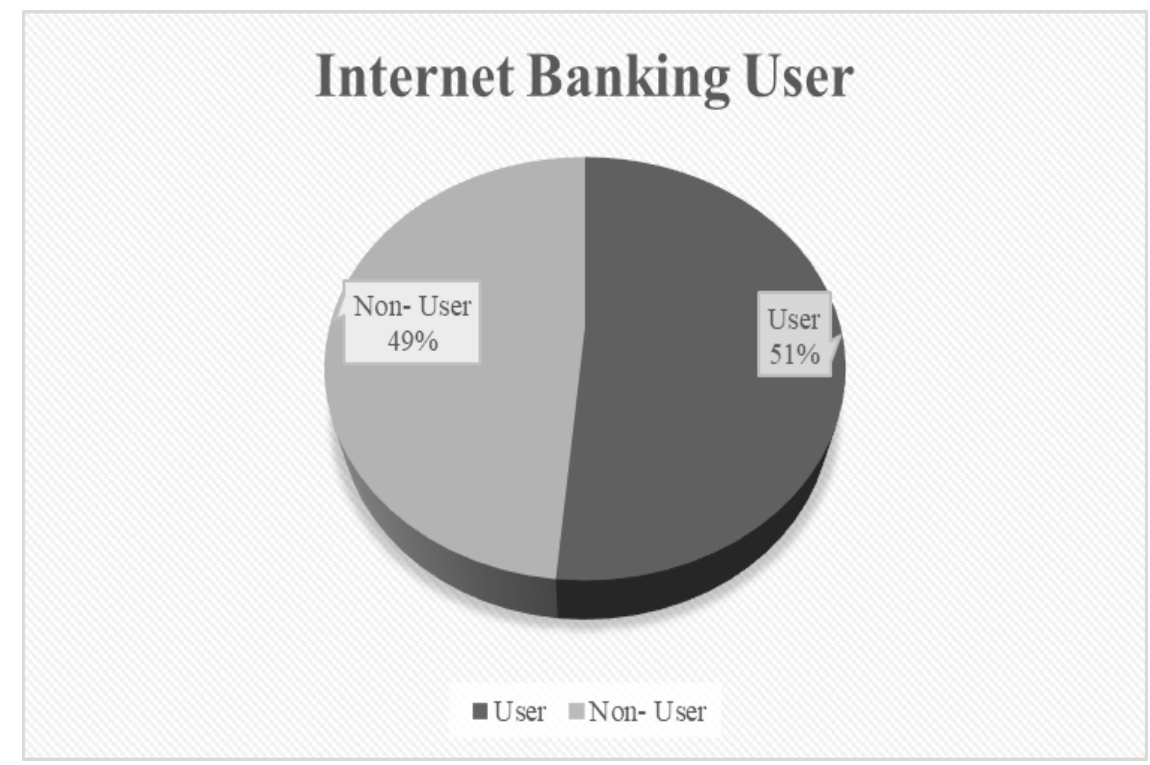

Figure 7: Internet Banking User

\section{Central Tendencies Measurement of Construct}

The overall means for the independent variables of service quality and convenience. The service quality section comprised Questions 1-5, while the convenience level section comprised Questions 610. See Table 2.

Table 2: Central Tendencies Measurement of Construct

\begin{tabular}{llllllll}
\hline Question & $\begin{array}{l}\text { Strongly } \\
\text { disagree } \\
\text { (1) }\end{array}$ & $\begin{array}{l}\text { Disagree } \\
\text { (2) }\end{array}$ & $\begin{array}{l}\text { Neutral } \\
\mathbf{( 3 )}\end{array}$ & $\begin{array}{l}\text { Agree } \\
\mathbf{( 4 )}\end{array}$ & $\begin{array}{l}\text { Strongly } \\
\text { agree } \\
\mathbf{( 5 )}\end{array}$ & Mean & $\begin{array}{l}\text { Standard } \\
\text { deviation }\end{array}$ \\
\hline SQ1 & $11.31 \%$ & $31.39 \%$ & $21.17 \%$ & $25.18 \%$ & $10.95 \%$ & 2.9307 & 1.20694 \\
\hline
\end{tabular}


Malaysian Journal of Social Sciences and Humanities (MJSSH), Volume 5, Issue 5, (page 24 - 43), 2020

DOI: https://doi.org/10.47405/mjssh.v5i5.416

\begin{tabular}{llllllll}
\hline SQ2 & $9.49 \%$ & $17.52 \%$ & $20.44 \%$ & $35.4 \%$ & $17.15 \%$ & 3.3321 & 1.22067 \\
SQ3 & $7.66 \%$ & $20.07 \%$ & $21.17 \%$ & $35.4 \%$ & $15.69 \%$ & 3.3139 & 1.18137 \\
SQ4 & $8.03 \%$ & $15.69 \%$ & $20.44 \%$ & $34.31 \%$ & $21.53 \%$ & 3.4562 & 1.21645 \\
SQ5 & $7.3 \%$ & $14.96 \%$ & $23.72 \%$ & $33.58 \%$ & $20.44 \%$ & 3.4489 & 1.18257 \\
C1 & $1.46 \%$ & $5.47 \%$ & $21.17 \%$ & $40.15 \%$ & $31.75 \%$ & 3.9526 & 0.93836 \\
C2 & $2.56 \%$ & $9.49 \%$ & $21.53 \%$ & $34.67 \%$ & $31.75 \%$ & 3.8358 & 1.05804 \\
C3 & $5.48 \%$ & $11.31 \%$ & $30.29 \%$ & $28.47 \%$ & $24.09 \%$ & 3.5365 & 1.14536 \\
C4 & $4.01 \%$ & $7.3 \%$ & $27.01 \%$ & $35.04 \%$ & $26.64 \%$ & 3.7299 & 1.05874 \\
C5 & $2.92 \%$ & $13.87 \%$ & $34.67 \%$ & $29.2 \%$ & $19.34 \%$ & 3.4818 & 1.04550 \\
\hline
\end{tabular}

Table 2 shows most of the respondents rated their responses more towards agree with the means for both independent variable questions exceeding 3.0. The SQ means ranged from 2.9307 to 3.4562. The means for Section C ranged from 3.4818 to 3.9526. The range of the standard deviations for all the variables were more than 1, which indicates that there was a high degree of dispersion in the data. SQ2 had the highest standard deviation among all the questions of 1.22067 , that shows predominantly diffusion from the collected data. The lowest standard deviation for $\mathrm{C} 1$ was 0.93836 , which indicates this question data had less dispersion.

\section{Reliability Analysis}

The measurement of internal consistency provides results in terms of coefficient alpha or Cronbach's Alpha, see Table 3.

Table 3: Reliability Analysis

\begin{tabular}{lllllll}
\hline Variables & $\begin{array}{l}\text { Cronbach's } \\
\text { Alpha }\end{array}$ & $\begin{array}{l}\text { Cronbach's Alpha } \\
\text { Items }\end{array}$ & Based on & Standardized \\
\hline Service Quality & 0.901 & 0.901 & & & 5 \\
Convenience & 0.885 & 0.886 & & & 5 \\
\hline
\end{tabular}

Table 3 shows the reliability test. According to Nunnally (1981), the Cronbach's alpha should exceed 0.7. However, Sekaran (2006) stated that a coefficient alpha value of more than 0.7 is accepted, as well. This study followed the proposition of Nunnally (1981), where the alpha value should exceed 0.7 to be accepted. All the variables are viewed as reliable as their Cronbach's alpha exceed the minimum value of 0.7 (Hair, Black, Babin, Anderson, \& Tatham, 2006). Therefore, the items adapted in the questionnaire for this study are reliable.

\section{Inferential Analysis}

Table 4 shows the scale of Pearson's Correlation Coefficient which the higher the correlation, the higher the quality of the connection.

Table 4: Scale of Pearson's Correlation Coefficient

\begin{tabular}{ll}
\hline Scale of correlation coefficient & Value \\
\hline $0<\mathrm{r} \leq 0.19$ & Very Low Correlation \\
$0.2 \leq \mathrm{r} \leq 0.39$ & Low Correlation \\
$0.4 \leq \mathrm{r} \leq 0.59$ & Moderate Correlation \\
$0.6 \leq \mathrm{r} \leq 0.79$ & High Correlation \\
$0.8 \leq \mathrm{r} \leq 1.0$ & Very High Correlation \\
\hline
\end{tabular}

Referring to Burns and Bush (2000), inferential examination is applied to reach conclusions with respect to components of the population in view of the variety of information. The aim of this investigation is to analyse individual variables with different factors, and their associations. In this study, both hypotheses are tried using the application of Pearson's coefficient of correlation and linear regression. The correlation coefficient of Pearson validates the after effects of the relations, while the 
linear regression analysis reveals the implications of the rundown model and the coefficients. A Pearson's correlation coefficient shows the quality, heading and immensity of the bivariate connections among every one of the factors that were measured at a provisional or proportion level. (Hair, Black, Babin, Anderson \& Tatham, 2006) stated the general guidelines about coefficient extent and the quality of the connection.

In this study, instead of a single-tailed test, the Pearson correlation review was performed using a twotailed test. Two-tailed tests were used to determine the positive or negative relationships between the independent variables. Two-tailed experiments are only used when the results are presented in two (positive or negative) ways. The relationships between the two variables can be seen as shown in the correlation Table 5.

Table 5: Correlation between Independent Variables

\begin{tabular}{llll}
\hline & & Service Quality & Convenience \\
\hline Service Quality & Pearson Correlation & 1 & $-.519^{* *}$ \\
& Sig. (2-tailed) & & .000 \\
Convenience & N & 274 & 274 \\
& Pearson Correlation & $-.519^{* *}$ & 1 \\
\multirow{2}{*}{ **. Correlation is significant at the 0.01 level (2-tailed). } & 274 & \\
& Sig. (2-tailed) & .000 & 274 \\
\hline
\end{tabular}

In the field of service quality, the result shows the connection between service quality and convenience is- 0.519 . This means the relationship is not correlated, and the variables are not relatively linked to each other. The findings show no multicollinearity unruly as the connections between variables are all less than 0.90 (Hair, Black, Babin, Anderson\& Tatham, 2006, p. 227). Therefore, it can be inferred that there is a negative correlation between Baby Boomers' independent variable and customer satisfaction with internet banking.

Once the reliability evaluation licensed that the questionnaire is reliable, the multiple regressions are also wished to govern whether the independent variables are correlated with the established variable. From the output derived from the Statistical Package for the Social Sciences (SPSS) evaluation, the researchers acquired the consequences on regression output inclusive of R-squared, ANOVA and coefficients that result in the speculation testing.

\section{Multiple Regression Analysis}

The purpose of multiple regression analysis is to look at connections between independent variables and a dependent variable (Hair, Dark, Babin, Anderson, \& Tatham, 2006, p. 169). Those connections can be shown by drawing a best-fit line or by calculating a relapse condition (Saunders, Lewis, Thornhill, 2009, p. 462; Zikmund, Babin, Carr \& Griffin, 2010, p. 567). As for the show ponder, the dependent variable is client fulfilment with the web managing accounts. There are two proposed autonomous factors which were clarified as related to benefit quality and comfort, see Table 6 .

Table 6: Model Summary

\begin{tabular}{lllll}
\hline Model & R & R Square & Adjusted R Square & $\begin{array}{l}\text { Std. Error of the } \\
\text { Estimate }\end{array}$
\end{tabular}

Table 6 shows, the "R" refers to the strength of the relationship between the forecast and the result from this research study that has been measured. Based on table $6, \mathrm{R}$ is equal to 0.963 , which shows that Baby Boomers strongly associate the two independent variables, which are service quality and comfort, with customer satisfaction with internet banking. The value of R-squared is 0.928 (92.8 per 
DOI: https://doi.org/10.47405/mjssh.v5i5.416

cent). This also means that 92.8 per cent of the independent variable (quality of service and convenience) data influences the dependent variable (customer satisfaction). Moreover, it also indicates that $92.8 \%$ of the total variance in the dependent variable is explained by the independent variable. The remaining 7.2 percent comes from other factors that are not part of this analysis.

\section{Linearity Test}

In this section, a linearity test was conducted to ensure the correlations were linear. The randomised scatter plot shows that the assumption of linearity was met. In this research, a linear relationship was shown by all the variables. The results of linearity testing are shown below in Figures 8 and 9 .

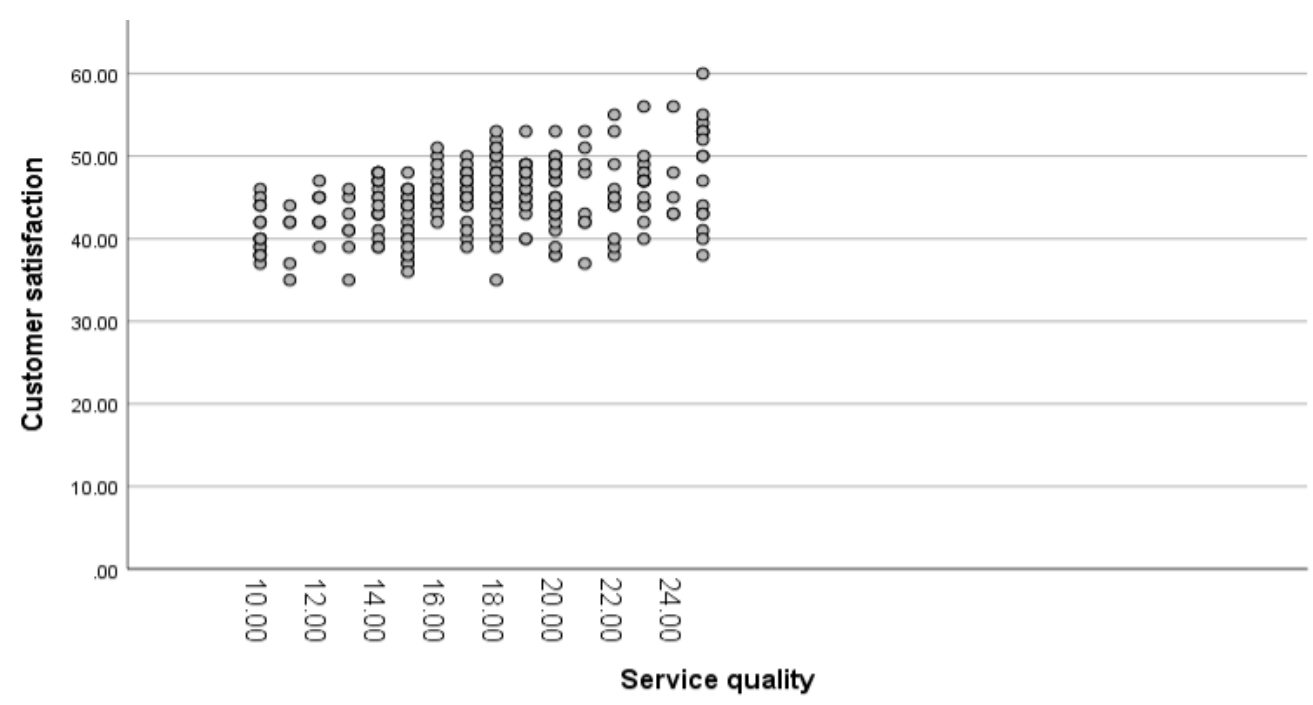

Figure 8: Linearity Relationship between Service Quality and Customer Satisfaction

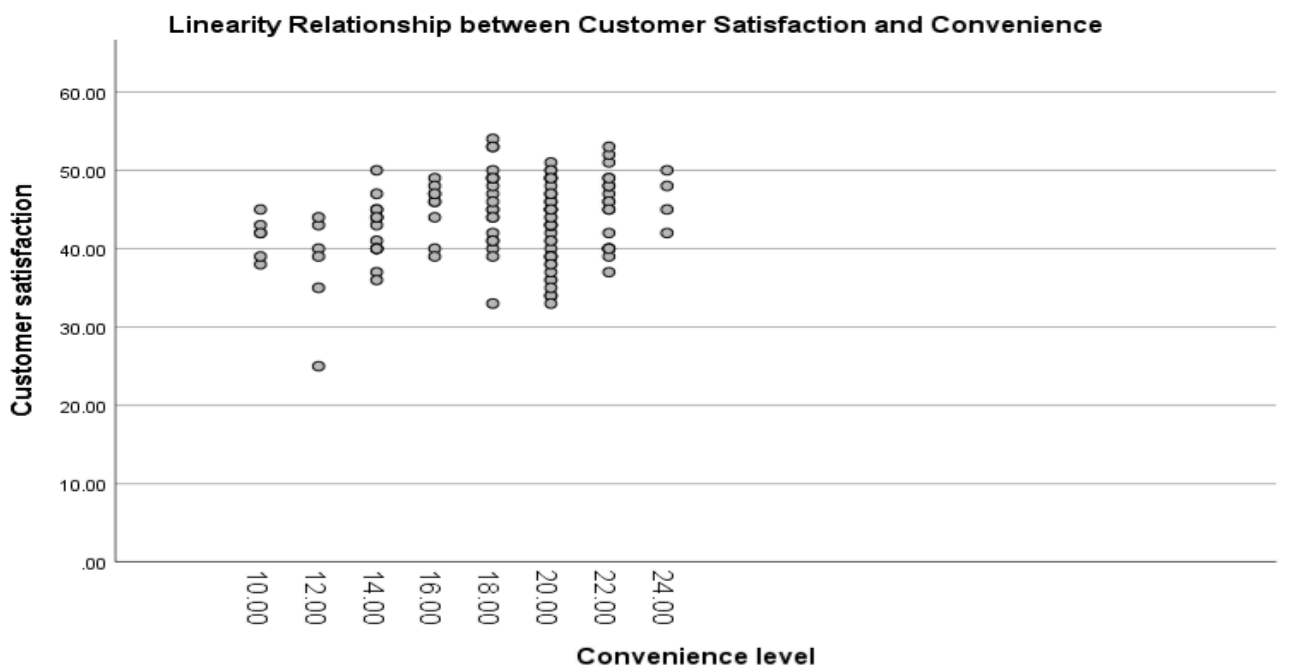

Figure 9: Linearity Relationship between Convenience and Customer Satisfaction

Figures 8 and 9 show the results of linearity testing in Bangsar, Kuala Lumpur, Malaysia, between the independent variables, service quality and comfort and the dependent variable, customer satisfaction. The scatter plot indicates an upward trend; thus, it is concluded that the relationship between comfort, quality of service and customer satisfaction is positive. 
The Sig value has an important role in the ANOVA table. The significance value should be $\mathrm{p}<0.05$ in the ANOVA table. Hair, Black, Babin, Anderson, and Tatham (2006) mentioned that it may be concluded that the overall model is significant if the p-value from the F-test is less than the alpha value of 0.05 , see Table 7 .

Table 7: Table ANOVA ${ }^{\mathrm{a}}$

\begin{tabular}{clllll}
\hline Model & Sum of Squares & df & Mean Square & F & Sig. \\
\hline Regression & 6081.699 & 2 & 3040.850 & 1737.496 & $.000^{\mathrm{b}}$ \\
Residual & 474.286 & 271 & 1.750 & & \\
Total & 6555.985 & 273 & & & \\
\hline
\end{tabular}

a. Dependent Variable: customer satisfaction

b. Predictors: (Constant), service quality, convenience level

From Table 7, it can be observed that the "Sig" value is $0.000(\mathrm{p}=0.000)$. This means that the model is fit to use for further analysis. Similarly, it also means that the independent variables, service quality and convenience, significantly affect the dependent variable, which is customer satisfaction.

The value of the convenience variable's unstandardized coefficient Betaon the level of customer satisfaction with internet banking among Baby Boomers is 1.012. While the standardized Beta confidence coefficient is interpreted as one standard deviation increase in comfort driving to an increase of 0.898 in standard deviation in customer fulfilment with site management of an Infant Boomers account. The p-value of comfort is 0.000 based on Table 8 , which is lower than the alphaestimate of 0.05 . In this way it is shown that comfort is notable in. Lapierre (2000) contended that clients esteem comfort, especially sparing time and exertion costs, not as it were when they make buys but too whereas getting to, tolerating and completing a benefit. In this way, comfort could be a critical figure that upgrades the level of client fulfilment since clients continuously look for comfort when they are making choices (Ong, Hong, Soh, Teh \&Tan 2014), see Table 8.

Table 8: Multiple Linear Regression on Independent Variables and Dependent Variable on Internet Banking among Baby Boomers. (Coefficients ${ }^{\mathrm{a}}$ )

\begin{tabular}{|c|c|c|c|c|c|c|c|}
\hline \multirow[b]{2}{*}{ Model } & \multicolumn{2}{|c|}{$\begin{array}{l}\text { Unstandardized } \\
\text { Coefficients }\end{array}$} & \multirow{2}{*}{$\begin{array}{c}\text { Standardized } \\
\text { Coefficients } \\
\text { Beta } \\
\end{array}$} & \multirow[b]{2}{*}{ t } & \multirow[b]{2}{*}{ Sig. } & \multicolumn{2}{|c|}{$\begin{array}{l}95.0 \% \text { Confidence } \\
\text { Interval for B }\end{array}$} \\
\hline & B & Std. Error & & & & $\begin{array}{l}\text { Lower } \\
\text { Bound }\end{array}$ & $\begin{array}{l}\text { Upper } \\
\text { Bound }\end{array}$ \\
\hline (Constant) & 8.606 & .619 & & 13.894 & .000 & 7.387 & 9.825 \\
\hline Convenience & 1.012 & .022 & .898 & 47.010 & .000 & .970 & 1.055 \\
\hline $\begin{array}{l}\text { Service } \\
\text { quality }\end{array}$ & 1.009 & .018 & 1.047 & 54.793 & .000 & .973 & 1.046 \\
\hline
\end{tabular}

a. Dependent Variable: customer satisfaction

Table 8 shows convenience accounts for most of the variation in customer satisfaction with internet banking among Baby Boomers between the two independent variables, where convenience has the highest unstandardized coefficient Beta value. The least contribution was from service quality, as shown by its low coefficients.

Service quality's unstandardized coefficient B value on the level of customer satisfaction towards internet banking is 1.009 , while the standardized coefficient Beta value shows a one standard deviation increase in service quality would lead to an increase of 1.047 in standard deviation in customer satisfaction with internet banking among Baby Boomers. Based on Table 8 , service quality's p-value of 0.000 is less than the significance level of 0.05 , which indicates that service quality is significant in explaining the variation in customer satisfaction with internet banking among Baby Boomers. This shows that there is a positive relationship between service quality and customer satisfaction towards internet banking among Baby Boomers. Therefore, higher service quality can trigger a higher level of customer satisfaction provided the services can satisfy the customers. The benefit of customer service 
which the customers are gained surpasses the desires of clients is most profitable to a bank because it can fulfil clients by assembly their needs (Selvakumar, 2015). Concurring to Thwaites and Vere (1995), clients will select a bank by evaluating the run and quality of the bank's administrations. Besides, Oliver (1980) moreover proposes that quality for the benefit.

Many respondents in this study agreed with claims about the value of quality of service. Hence, the Internet banking sector cannot ignore the importance of service quality because bank protection is one of the elements. Bank authority must ensure that Baby Boomers feel safe when they use internet banking.

\section{Hypothesis Results}

All the hypothesised expectations are noteworthy since their p-values are less than 0.05 , see Table 9 . The result infers that both independent variables (service quality and convenience) have positive relations with the dependent variable as the significant value is 0.000 , which is less than 0.05 , and thus the hypothesis is supported. From the results shown above, it is obvious that the most crucial factor in this research is convenience because its Beta $(\beta)$ value is the highest, which is 1.012. For instance, internet banking in Malaysia must be convenient to the Baby Boomers as they are the users. This convenience is experienced in time saving and user friendliness, which function to make internet banking easy and convenient to Baby Boomers. The second vital factor in this research is service quality as the Beta $(\beta)$ value is the second highest at 1.009 . The level of internet banking service quality affects the satisfaction of the Baby Boomers with it, thereby impacting on internet banking adoption. Overall, this shows that both independent variables have important relationships with the dependent variable of customer satisfaction among Baby Boomers towards internet banking.

Table 9: Hypothesis Results

\begin{tabular}{lllll}
\hline Hypothesis & Sig & Results & $\begin{array}{c}\text { Gradient } \\
\boldsymbol{\beta}\end{array}$ \\
\hline H1 & $\begin{array}{l}\text { There will be a direct significant and } \\
\text { correlation reflect between the } \\
\text { Service Quality towards the Customer }\end{array}$ & $\begin{array}{c}0.000 \\
(\mathrm{P}<0.050)\end{array}$ & Supported & 1.009 \\
$\begin{array}{l}\text { Satisfaction } \\
\text { There will be a direct significant and } \\
\text { correlation reflect between the } \\
\text { Convenience towards the Customer } \\
\text { Satisfaction. }\end{array}$ & $\begin{array}{c}(\mathrm{P}<0.50) \\
\text { S }\end{array}$ & Supported & 1.012 \\
\hline
\end{tabular}

Table 9 also shows the pilot was carried out to test reliability of the study been conducted on 274 respondents. It was found that the independent variables were directly related with the dependent variable. Besides that, researchers conducted a descriptive analysis on collected demographic data such as the respondents' age range, gender, education level, race, marital status and whether they were internet banking users.

Furthermore, the researchers also examined the reliability test for the dependent variable and linearity testing for each variable to determine whether relationships existed between the independent variables and the dependent variable. Finally, researchers conducted analyses through correlation analysis and multiple regression analysis to inspect the relationships between independent variables and the dependent variable. Moreover, by applying the outcome of every test conducted in this research, it is highly possible to determine the significant limitations and findings of this study and give recommendations for future study. 


\section{Conclusion}

This section outlines a summary of the discussion, implications and limitations of the study, ethical considerations, recommendations for further research and the conclusion.

In this study, the questionnaire was completed by 274 respondents. Most of the respondents were born in the years $1958-1964$. Out of 274 respondents, 141 of them were male, while the remaining were female, and most of them were married. One hundred and twenty respondents completed their education in high school, while only 12 respondents completed their study at the master's degree level and above. Out of 274 respondents, the percentage of users of internet banking was slightly more compared to non-users.

The correlation test and multiple regression were analysed, see Table. 10.

Table 10: Result of the Pearson's Correlation and Multiple Regression Analysis

\begin{tabular}{ll}
\hline Correlation Test & - Service Quality: 1 \\
Multiple Regression Analysis & Convenience: 0.519 \\
& $\bullet$ R-squared: $92.8 \%$ \\
& - ANOVA: 0.000 \\
& - P-value of Service Quality: 0.000 \\
&
\end{tabular}

Table 10 shows the these results were obtained from 274 respondents and were analysed by using the SPSS software. The correlation test included Pearson correlation analysis of the perceptions about internet banking among Baby Boomers. Service quality was found to be more closely related to the perceptions about internet banking among Baby Boomers than convenience.

The multiple regression analysis provided a description of the model, ANOVA and a table of coefficients. In the model description, the R-squared value is 92.8 percent, which means that the dependent variables influenced 92.8 percent of the independent variable. The value of significance for ANOVA is known as an acceptable value if the outcome is no more than 0.05 . Once it reaches the number it is not approved.

This research study was to determine the perceptions on internet banking among Baby Boomers. Two factors have been described as impacting them when using internet banking, which are the quality of service and the comfort of internet banking. The implications of this study could affect the adoption of internet banking among Baby Boomers. Future research along the lines of this study would be benefitted for the banking industries in making decision and applying or refining the service area.

The results for the service quality factor have implications for improving the quality of service provided by Malaysian internet banking, which can increase the number of Baby Boomers using the services. The results of the analyses show that Baby Boomer customers neither agree nor disagree that they are satisfied with the quality of the service provided. The explanation for this could be due to their distressing experiences of using internet banking, such as failed transactions and difficulties in following the internet banking process, making it easier for them to communicate with a bank employee. This implicates that the banking industry must improve their internet banking services. It shows that internet banking in Malaysia must provide good service quality that enables Baby Boomers. Lastly, the results on the implications of the relationships between service quality and customer satisfaction are highly significant because if Baby Boomers are satisfied with internet banking, they will increase their adoption of the services.

Meanwhile, as for the factor of convenience, the results show that respondents were closer to agreeing that internet banking offers advantages such as time saving and the ability to perform transactions anywhere and anytime. According to the results, it is proved that internet banking is very convenient for them to use. It could save their time from queuing in the bank for long periods of time and help in 
avoiding crowds, and it is also user friendly, which would make it easy for them to check their transaction records.

However, on the aspect of security, respondents were still unsure that online services are safe enough, but they were still using it for the sake of other advantages. The reasons for feeling unsafe may have been due to hacking incidents or their cautious behaviour. The implication of the perceived convenience level was that Baby Boomers were affected by the convenience of internet banking in choosing to use the services.

The findings also show the two independent variables had positive relationships with and significantly affected customer satisfaction with internet banking. This study offered answers to the research questions through the research process and achieved the study objectives. The findings of this study are that poor quality of service and the high security risks associated with internet banking along with the caution and comfort expectations of Baby Boomers influence the satisfaction of Baby Boomers with internet banking.

Limitations of this research were basically the location of this research as it was only conducted in the Bangsar area, and the target respondents were only Baby Boomers. As is generally known, Baby Boomers are a group of people with mostly reserved personalities, thus being more likely to keep to themselves instead of being friendly, making this one of the limitations faced during this research. Another limitation is researchers needed to aid the respondents (Baby Boomers) when conducting the survey.

The researchers of this study have some suggestions for the further research. The R-squared value in multiple regression analysis is 0.928 , which means $92.8 \%$ of the independent variables affect the dependent variable. Other objective variables not included in this research are shown by the remaining 7.2 per cent. Instead of the concepts involved in this analysis, further studies can include other independent variables based on other theoretical bases.

\section{References}

Ahanger, R. G. (2011). An Investigation into the Determinants of Customers' Preferences and Satisfaction of Internet Banking (Empirical Study of Iranian Banking Industry). Journal of Applies Sciences, 11(3), 426-437.

Ahmed, E., \& Phin, G. (2016). Factors influencing the adoption of internet banking in Malaysia. Journal of Internet Banking and Commerce, 21(1), 1-28.

Al-Ajam, A., \& Nor, K. (2013). Internet Banking Adoption: Integrating Technology Acceptance Model and Trust. European Journal of Business and Management, 5(3), 207-215.

Ali, A. (2016). Customers' acceptance of internet banking: An empirical study in Lebaon. The International Journal of Management, 5(2), 8-31.

AL-Subari, S. (2017). Online banking adoption among academicians at MTUN University in Malaysia. (Unpublished doctoral dissertation). University Tun Hussein Onn Malaysia, Batu Pahat, Johor, Malaysia

Amin, H. (2009). An Analysis of Online Banking Usage Intentions: An Extension of the Technology Acceptance Model. International Journal of Business and Society, 10(1), 27-40.

Amin, M., Isa, Z., \& Fontaine, R. (2011). The role of customer satisfaction in enhancing customer loyalty in Malaysian Islamic banks. The Service Industries Journal, 31(9), 1519-1532.

Andaleeb, S. S. and Basu, A. K. (1994), Technical Complexity and Consumer Knowledge as Moderators of Service Quality Evaluation in the Automobile Service Industry, Journal of Retailing, 70(4), 367-381.

Asian Institute of Finance. (2016). Digital Banking: Measuring the Consumer Pulse in Malaysia (pp. 2-35). Kuala Lumpur: Asian Institute of Finance.

Augustine, A. (2017). Fintech for boomers: Follow the money. U.S. Economic Watch, 1-5. 
DOI: https://doi.org/10.47405/mjssh.v5i5.416

Bank Negara Malaysia (2019). Payment Statistic Internet Banking and Mobile Banking Subscribers (end of period). Retrieved 10 June 2019, from http://www.bnm.gov.my/index.php?ch=34\&pg=163\&ac $=4 \& b b=$ file

Beauchamp, M.B., Ponder, N. (2010). Perceptions of retail convenience for in-store and online shoppers. Marketing Management Journal, 20(1), 49-65.

Bell, S. (1999). Image and consumer attraction to intraurban retail areas: an environmental psychology approach. Journal of Retailing and Consumer Services, 6(2), 67-78.

Bender, W. C. (1964). Consumer purchase-costs-Do retailers recognize them? Journal of Retailing, $40,1-8$

Berry, L. L. (2016). Revisiting "big ideas in services marketing" 30 years later, Journal of Services Marketing, 30(1), 3-6.

Berry, L. L., Seiders, K., \& Grewal, D. (2002). Understanding Service Convenience. Journal of Marketing, 66(3), 1-17.

Bradley, L., \& Stewart, K. (2003). A Delphi study of Internet banking. Marketing Intelligence \& Planning, 21(5), 272-281.

Burns, A.C. \& Bush, R.F. (2000). Marketing research. Upper Saddle River, N.J: Prentice Hall.

Camilleri, S., \& Grech, G. (2017). The relevance of age categories in explaining internet banking adoption rates and customers' attitudes towards the service. Journal of Applied Finance \& Banking, 7(2), 29-47.

Chen, M. C., Chang, K. C., Hsu, C. L., \& Yang, I. C. (2011). Understanding the relationship between service convenience and customer satisfaction in home delivery by Kano model. Asia Pacific Journal of Marketing and Logistics, 23(3), 386-410.

Chong, H., Islam, M., Manaf, A., \& Mustafa, W. (2015). Users satisfaction towards online banking in Malaysia. International Business Management, 9(1), 15-27.

Dietz, J. (2003). defining markets, defining moments: America's 7 generational cohorts, their shared experiences, and why businesses should care, The Journal of Consumer Marketing, 20(2/3), 172-174.

Duarte, P., Costa e-Silva, S., \& Ferreira, M. (2018). How convenient is it? Delivering online shopping convenience to enhance customer satisfaction and encourage e-WOM. Journal of Retailing and Consumer Services, 44, 161-169.

Emrich, O., Paul, M., \& Rudolph, T. (2015). Shopping Benefits of Multichannel Assortment Integration and the Moderating Role of Retailer Type. Journal of Retailing, 91(2), 326-342.

Farquhar, J.D., Rowley, J. (2009). Convenience: a services perspective. Marketing Theory, 9(4), 425438.

Firdous, S., \& Farooqi, R. (2017). Impact of internet banking service quality on customer satisfaction. Journal of Internet Banking and Commerce, 22(1), 1-17.

Fornell, C., Johnson, M. D., Anderson, E. W., Cha, J., \& Everitt Bryant, B. (1996). Growing the trust relationship. Journal of Marketing, 60(4), 7-18.

Frey, W. H. (2010). Baby Boomers and the new demographics of America's seniors. GenerationsJournal of the American Society on Aging, 34(3), 28-37.

Gehrt, K., \& Yale, L. (1993). The dimensionality of the convenience phenomenon: A qualitative reexamination. Journal of Business and Psychology, 8(2), 163-180.

Giese, J., \& Cote, J. (2002). Defining Consumer Satisfaction. Academy Of Marketing Science Review, 2000(1), 1-14.

Gilliam, J. E., Chatterjee, S., \& Zhu, D. (2010). Determinants of risk tolerance in the baby boomer cohort. Journal of Business \& Economies Research, 8(5), 79-87.

Goh, M., Yeo, S., Lim, K., \& Tan, S. (2016). Understanding customer satisfaction of internet banking: A case study in Malacca. Procedia Economics and Finance, 37 (1), 80-85.

Golden, D., \& Regi, S. (2019). Customers' satisfaction towards online banking an analysis. SSRN Electronic Journal, 2(1), 13-21.

Gorrell, M. (2008). When Marketing Tourism, Age Matters, Expert Says, Retrieved 19 June 2019 from https://www.eturbonews.com/4925/when-marketing-tourism-age-matters-expert-say/

Grönroos, C. (2000). Service management and marketing: A customer relationship management approach (2nd Ed.). Chichester: John Wiley and Sons, Ltd.

Hair, J.F., B. Black, B. Babin, R.E. Anderson, R.L. Tatham. (2006). Multivariate Data Analysis (6th Ed.). Upper Saddle River, New Jersey: Pearson Education, Inc. 
Hamenda, A. (2019). An integrated model of service quality, price fairness, ethical practice and customer perceived values for customer satisfaction of sharing economy platform. International Journal of Business and Society, 19(3), 709-724

Hawkins, D. I., Mothersbaugh, D. L., \& Best, R. J. (2013). Consumer behaviour: Building marketing strategy. USA: McGraw-Hill.

Herrmann, R. O., \& Beik, L. L. (1968). Shoppers' movements outside their local retail. Journal of Marketing, 32(4), 45-51.

Hilt, M., \& Lipschultz, J. (2005). Mass media, an aging population, and the Baby Boomers (1st ed., p. 11). Mahwah, N.J.: Lawrence Erlbaum.

Hui, M., Thakor, M., \& Gill, R. (1998). The Effect of Delay Type and Service Stage on Consumers' Reactions to Waiting. Journal of Consumer Research, 24(4), 469-480.

Johns, N. (1999). What is this thing called service? European Journal of Marketing, 33(9-10), 958973.

Khan, H., Mir, M. M., Khan, K., Reza, A., Khan, E., \& Janjua, D. H. (2016). Analysis of electronic banking services \& its issues in Pakistan. European Journal of Business and Management, $8(34), 1-8$.

Krejcie, R., \& Morgan, D. (1970). Determining sample size for research activities. educational and psychological measurement, 30(3), 607-610.

Lapierre, J. (2000). Customer-perceived value in industrial contexts. Journal of Business \& Industrial Marketing, 15(2-3), 122-140.

Lee, S., \& Moghavvemi, S. (2015). The Dimension of Service Quality and Its Impact on Customer Satisfaction, Trust, and Loyalty: A Case of Malaysian Banks. Asian Journal of Business and Accounting, 8(2), 91-121.

Lee. J. Y., Chia. A. M., Choong. L. W., \& Foo. K.Y.J. (2017). Customers' satisfaction towards online banking in Malaysia: A primary data analysis. (Unpublished doctoral dissertation). Universiti Tunku Abdul Rahman, Kampar, Perak, Malaysia.

Levesque, T., \& McDougall, G.H.G. (1996). Determinants of customer satisfaction in retail banking. International Journal of Bank Marketing, 14(7), 12-20.

Lim. C. C., Lim. X. C., Ng. S. N., Ng. W. X., \& Tan. Y. J. (2013). Customer resistance to mobile banking services: An empirical study among Baby Boomers in Malaysia urban areas. (Unpublished doctoral dissertation). Universiti Tunku Abdul Rahman, Kampar, Perak, Malaysia.

Malaysian Communications and Multimedia Commission. (2017). Internet users survey 2017 (pp. 151). Selangor, Malaysia: Malaysia Communications and Multimedia Commission.

Mashal, A and E. Ahmed. (2015). Effects of TQM practices on banking sector performance: The case of Jordan. Journal of Applied Finance and Banking, 5(6), 113-126.

Maybank2u.com (2000). Maybank Launches Country's First Internet Financial Portal. Retrieved 10 June 2019, from

https://www.maybank2u.com.my/mbb_info/m2u/public/personalDetail04.do?channelId=Person al\&cntTypeId $=0 \& \operatorname{cntKey}=\mathrm{AU} 00.06 .09 \&$ programId=AU02.02-

ArchiveNews\&newsCatId=/mbb/AU-AboutUs/AU02-

Newsroom $/ 2000 / 06 \&$ chCatId $=/ \mathrm{mbb} /$ Personal

McLeod, E. (2009). The use (and disuse) of mobile phones by baby boomers. International Journal of Emerging Technologies and Society, 7(1), 28-38.

Mmutle, T., \& Shonhe, L. (2017). Customers' perception of Service Quality and its impact on reputation in the Hospitality Industry. African Journal Of Hospitality, Tourism and Leisure, 6(3), 1-25.

Morris, M. G., Venkatesh, V., Ackerman, P. L. (2005). Gender and age differences in employee decisions about new technology: An extension to the theory of planned behaviour, IEEE Transactions on Engineering Management, 52(1), 69-84

Muffatto, M \& Panizzolo, R. (1995). A process-based view for customer satisfaction. International Journal of Quality and Reliability Management, 12(9), 154-169.

Naik, C. N., Gantasala, S. B., \& Prabhakar, G. V. (2010). Service Quality (Servqual) and its Effect on Customer Satisfaction in Retailing. European Journal of Social Sciences, 16(2), 231-241.

Ndikubwimana, P., \& Berndt, A. (2016). Service quality and customer Satisfaction among bank clients in Rwanda. British Journal of Economics, Management \& Trade 13(4), 1-11. 
Nui. P. V., \& Ekin, S. (2001). An empirical investigation of the Turkish consumers' acceptance of internet banking services. International journal of Bank Marketing, 19(4), 156-165.

Nunnally, J.C. (1981). Psychometric theory, (3rd Ed.), New Delhi: Tata McGraw-Hill

Oliver. R. L. (1980). A cognitive model of the antecedents of satisfaction decisions. Journal of Marketing Research, 17(4), 460-469.

Ong, T. S., Hong, Y. H., Teh, B. H., Soh, P. C. H., \& Tan, C. P. (2014). Factors that affect the adoption of internet banking in Malaysia. International Business Management, 8(2), 55-63.

Osman, Z., Mohamad, L., \& Mohamad, R. (2015). An empirical study of direct relationship of service quality, customer satisfaction and bank image on customer loyalty in Malaysian commercial banking industry. American Journal of Economics 2015, 5(2), 168-176

Ostrom, A. L., Parasuraman, A., Bowen, D. E., Patrício, L. \& Voss, C.A. (2015). Service research priorities in a rapidly changing context. Journal of Service Research, 18(2), 127-159.

Poon, W., Yong, G., \& Lam, W. (2009). An insight into the attributes influencing the acceptance of internet banking: the consumers' perspective. International Journal of Services and Standards, 5(1), 81-94.

Porter, C., \& Donthu, N. (2006). Using the technology acceptance model to explain how attitudes determine Internet usage: The role of perceived access barriers and demographics. Journal of Business Research,59(9), 999-1007.

Quinn, J. F. (2010). Work, retirement, and the encore career: Elders and the future of the American workforce. Generations- Journal of the American Society on Aging,34(3), 45-55.

Rahi, S., Ghani, M., Alnaser, F., \& Yasin, N. (2017). Adoption of internet banking: extending the role of technology acceptance model (tam) with e-customer service and customer satisfaction. World Applied Sciences Journal, 35(9), 1918-1929.

Reichheld, F.F. (1993). Loyalty-based management. Harvard Business Review, 71(2), 64-73.

Said, A., Shuib, A., Ayob, N., \& Yaakub, F. (2013). An evaluation of service quality from visitors' perspectives: The case of Niah national park in Sarawak. International Journal of Business and Society, 14(1), $61-78$.

Saunders, M., Lewis, P., \& Thorhill, A. (2009). Research methods for business students (5th Ed.), Harlow, UK: Pearson Education.

Seiders, K., Voss, G.B., Godfrey, A.L., \& Grewal, D. (2007). SERVCON: Development and Validation of a Multidimensional Service Convenience Scale. Journal of the Academy of Marketing Science, 35 (2), 144-156.

Sekaran, U. (2000). Research method for business: Skill-building approach, (3th Ed.). USA: John Wiley and Son, Inc.

Selvakumar, J.J. (2015). Impact of service quality on customer satisfaction in public sector and private sector banks. PSG Institute of Management.

Shariq S. (2006). Internet Banking in Pakistan. (Unpublished doctoral dissertation). Luleå University of Technology, Sweden.

Silvio. J.C., Gail. G. (2017). The relevance of age categories in explaining internet banking adoptions rates and customers' attributes towards the service. Journal of Applied Finance \& Banking, $7(2), 29-47$.

Suh, B., \& Han, I. (2002). Effect of trust on customer acceptance of Internet banking. Electronic Commerce Research and Applications, 1, 247-263.

Thwaites, D., \& Vere, L. (1995). Bank selection criteria: A student perspective. Journal of Marketing Management, 11(1), 133-149.

Toor, A., Hunain, M., Hussain, T., Ali, S., \& Shahid A. (2016). The impact of e-banking on customer satisfaction: evidence from banking sector of Pakistan. Journal of Business Administration Research, 5(2), 27-40.

Vuori S, Holmlund-Rytkönen, M. (2005). 55+ people as Internet users. Marketing Intelligence and Planning, 23(1), 58-76.

Weingarten R.M. (2009). Four generations, one workplace: A gen X-Y staff Nursesview of team building in the emergency department. Journal of Emergency Nursing, 35(1), 27-30.

World Health Organisation. (2012). Ageing and life course. Retrieved 10 June 2019 from http://www.who.int/ageinhug/en

World Health Organisation. (2010). Population ageing. Retrieved 10 June 2019, from https://www.who.int/features/qa/72/en/ 
Yeoh. S. F., \& Benjamin. C.Y. F. (2011). Internet banking adoption in Kuala Lumpur: An application of UTAUT model. International Journal of Business and Management, 6(4), 161-167.

Zeithaml, V. and Bitner, M. (2003). Service marketing: Integrating customer focus across the firm. New York: McGraw-Hill.

Zikmund, W. G., Babin, B. J., Carr, J. C., \& Griffin, M. (2010). Business research method (8th Ed.), USA: South Western Cengage Learning.

\section{Authors' Details}

1. Geraldine De Mello, PhD, is an Associate Professor at the Academy of Language Studies, Universiti Teknologi MARA Melaka. She has taught a number of English courses at the diploma and degree levels. She is actively involved in writing and has written several books. Some of her research articles have also been published in local and international indexed journals. She is also keen in innovating and producing educational tools to help educators teach in a fun way and creating a positive atmosphere among the students in the classrooms.

Email address : geraldine@uitm.edu.my

HP : : $\quad$ +60123736259

Address : Jabatan Bahasa Inggeris, Akademi Pengajian Bahasa, UiTM Cawangan Melaka, Kampus Alor Gajah, Melaka.

2. Mr. Vasudevan Naidu Kanan is currently a Project Manager in the Business Communication Department of O'Connor's Engineering Sdn. Bhd, Kuala Lumpur. He did his Masters in Global Business from SEGI University Kota Damansara. He used to work in CIMB Group from the department of Client Management. His research interest is in social sciences, business and information technology.

Email address : evanleo05@gmail.com

HP : : +60129790535

Address : O'Connor's Engineering Sdn. Bhd. Bagunan O'Connor, No.13 Jalan 223, 46100 Petaling Jaya, Selangor.

3. Ms. Kausalya Muthutamilselvan is a STPM leaver. She has been waiting for her a university enrolment to pursue her territory education in Law. Her experience in research projects during her school embarks her to explore further in multi discipline research. Presently, her passion into English language teaching, linguistics field as well as performing arts.

Email address : Legalya0808@gmail.com

HP : : $\quad: 60166905178$

Address : No. 3413, Lorong 2A/ 5 Taman Mutiara, Sg. Kob Karangan, 09700, Kulim, Kedah

4. Shasthrika Baskaran obtained her Master's in Educational TESL from University Putra Malaysia and she is currently a lecturer who specialises in teaching English Proficiency for students of University of Malaya. She also specialises in presentation \& communication skills courses. She is also a part-time lecturer at a private university where she offers courses in critical thinking skills.

Email address : shasthrika@gmail.com

HP : : +60167961583

Address : Wisma RnD University of Malaya, Jalan Pantai Baharu, Taman Bukit Pantai, 59100 Kuala Lumpur, Wilayah Persekutuan Kuala Lumpur. 
DOI: https://doi.org/10.47405/mjssh.v5i5.416

5. Mr. Isai Amutan Krishnan is currently doing his $\mathrm{PhD}$ at the Faculty of Languages and Linguistics, University of Malaya (UM), and his area of interests are in human resource development \& management, ELT, and performing arts. He is also a freelance consultant locally and abroad.

Email address : amuthan.isai@gmail.com,

HP : : +60123845100

Address $\quad$ : Faculty of Languages and Linguistics, University of Malaya, 50603 Kuala Lumpur

6. i) Yeap Pei Xin; ii) Vasithra Devamanickam; iii) Nur Izyan Syazwani Binti Ismail Marzuki; iv) Siti Nur Aminah Binti Wan Ahmad Daknam; v) Siti Noratikah Binti Adnan; vi) Nur Sharina Binti Muhammad Khairul; vii) Nur Hikmah Binti Ramli, they are Diploma students are Diploma students from University of Malaya Centre for Continuing Education (UMCCeD). They are from Diploma in Accounting, Management and Business Management courses. They are very much interested in exploring research fields. 